\title{
ANALISIS PENGEMBANGAN PARIWISATA HALAL DI KECAMATAN SIAK
}

\section{HALAL TOURISM DEVELOPMENT ANALYSIS IN SIAK DISTRICT}

\begin{tabular}{|c|}
\hline $\begin{array}{l}\text { Amir Syamsuadi } \\
\text { Universitas Abdurrab, }^{1} \\
\text { Indonesia }^{1} \\
\text { email: } \\
\text { amir.syamsuadi@univr } \\
\text { ab.ac.id }\end{array}$ \\
\hline $\begin{array}{l}\text { Liza Trisnawati }^{2} \\
\text { Universitas Abdurrab, } \\
\text { Indonesia }{ }^{2} \\
\text { email: } \\
\text { liza.trisnawati@univrab }\end{array}$ \\
\hline ac.id \\
\hline $\begin{array}{l}\text { Luluk Elvitaria }{ }^{3} \\
\text { Universitas Abdurrab, } \\
\text { Indonesia }{ }^{3} \\
\text { email: } \\
\text { luluk.elvitaria@univrab }\end{array}$ \\
\hline ac.id \\
\hline $\begin{array}{l}\text { IJI Publication } \\
\text { p-ISSN: } 2774-1907 \\
\text { e-ISSN: } 2774-1915 \\
\text { Vol. 1, No. 3, pp. 212- } \\
\text { 218, Juli 2021 }\end{array}$ \\
\hline
\end{tabular}

\section{PENDAHULUAN}

Dewasa ini pariwisata adalah salah satu sektor unggulan yang memberikan kontribusi sognifikan terhadap pendapatan nasional Indonesia, Menparekraf menjelaskan bahwasanya dalam beberapa tahun terakhir ini, kontribusi sektor pariwisata terhadap perekonomian nasional semakin besar (Destiana dan Astuti, 2019).

Pariwisata halal mengedepankan pemenuhan kebutuhan dasar umat Islam di destinasi wisata, seperti beribadah, bersuci, dan berwisata sesuai ketentuan syariah. Potensi perjalanan yang dilakukan wisatawan muslim menunjukkan peningkatan yang positif (Widagdyo, 2015).

Pengembangan pariwisata di Indonesia telah tercermin dalam rencana strategi yang dirumuskan oleh Kementerian Kebudayaan dan Pariwisata Republik Indonesia, yakni: (1) meningkatkan kesejahteraan masyarakat dengan membuka kesempatan berusaha dan lapangan pekerjaan serta pemerataan pembangunan di bidang pariwisata; mewujudkan pembangunan pariwisata yang berkesinambungan sehingga memberikan manfaat sosial-budaya, sosial ekonomi bagi masyarakat dan daerah, serta terpeliharanya mutu lingkungan hidup; (3) meningkatkan kepuasan wisatawan dan memperluas pangsa pasar; (4) menciptakan iklim yang kondusif bagi pembangunan pariwisata Indonesia sebagai berdayaguna, produktif, transparan dan bebas KKN untuk melaksanakan fungsi pelayanan kepada masyarakat, dalam institusi yang merupakan amanah yang dipertanggungjawabkan.

Berdasarkan temuan-temuan uji lapangan terdapat empat aspek penting yang harus diperhatikan untuk menunjang suatu pariwisata halal (Chookaew et al, 2015) yakni, (1) Lokasi: Penerapan sistem Islami di area pariwisata. Lokasi pariwisata yang dipilih merupakan yang diperbolehkan 
kaidah Islam dan dapat meningkatkan nilai-nilai spiritual wisatawan;

Transportasi: Penerapan sistem, seperti pemisahan tempat duduk antara laki-laki dan wanita yang bukan mahram sehingga tetap berjalannya syariat Islam dan terjaganya kenyamanan wisatawan; (3) Konsumsi: Islam sangat memperhatikan segi kehalalan konsumsi, hal tersebut tertuang dalam Q.S Al-Maidah ayat 3. Segi kehalalan disini baik dari dari sifatnya, perolehannya maupun pengolahannya. Selain itu, suatu penelitian menunjukkan bahwa minat wisatawan dalam makanan memainkan peran sentral dalam memilih tujuan wisata (Moira, Mylonopoulos, dan Kondoudaki, 2012), (4) Hotel: seluruh proses kerja dan fasilitas yang disediakan berjalan sesuai dengan prinsip halal. Pelayanan disini tidak sebatas dalam lingkup makanan maupun minuman, tetapi juga dalam fasilitas yang diberikan seperti spa, gym, kolam renang, ruang tamu dan fungsional untuk laki-laki dan perempuan sebaiknya terpisah.

Menurut Tessmer dan Richey pengembangan memusatkan perhatiannya tidak hanya pada analisis kebutuhan, tetapi juga isu-isu luas tentang analisis awal-akhir, seperti analisis kontekstual. Pengembangan bertujuan untuk menghasilkan produk (Sumarno, 2012).

Wisata halal lebih luas dari wisata religi yaitu wisata yang didasarkan pada nilai-nilai halalIslam. Seperti yang dianjurkan oleh World Tourism Organization (WTO), konsumen wisata halal bukan hanya umat muslim tetapi juga non muslim yang ingin menikmati kearifan lokal (Sofyan, 2012).

Kriteria umum pariwisata halal ialah; pertama, memiliki orientasi kepada kemaslahatan umum. Kedua, memiliki orientasi pencerahan, penyegaran, dan ketenangan. Ketiga, menghindari kemusyrikan dan khurafat. Keempat, bebas dari maksiat. Kelima, menjaga keamanan dan kenyamanan. Keenam, menjaga kelestarian lingkungan. Ketujuh, menghormati nilai-nilai sosial budaya dan kearifan lokal.

Berdasarkan Keputusan Menteri Kebudayaan dan Pariwisata Nomor: KM.13/PW.007/MKP/2004 tentang Penetapan Istana Siak, Balai Kerapatan Tinggi, Makam Sultan Syarif Kasim II, Mesjid Raya Syahabuddin dan Kompleks Makam Koto Tinggi sebagai Peninggalan Sejarah, Situs, dan Kawasan yang dilindungi di Kecamatan Siak (Sidiq dan Sidiq, 2015).

Pengakuan dan penghargaan dari Pemerintah Pusat di atas, semakin mempertegas Kabupaten Siak yang telah lekat dengan ikon wisata budaya sejarah dan Budaya melayu di Provinsi Riau (Syamsuadi, 2018) dengan tagline "Siak the Truly Malay", karena memiliki visi pengembangan budaya melayu yang agamis, dengan bekal budaya dan sejarah kemelayuan yang bersendikan syarak dan syariat Islam.

Program pariwisata halal merupakan sebuah rangkaian program kepariwisataan dengan memberikan kualitas layanan prima, baik dari sisi konsumsi, transportasi maupun akomodasi bagi para wisatawan. Konsumsi dimaksud haruslah makanan-makanan yang halal lagi baik menurut persepektif Islam, dijajakan dengan nilai jual yang masuk akal dan tidak memberatkan.

Sementara transportasi maupun akomodasi dimaksud adalah transportasi dan akomodasi yang tidak bercampur antara lakilaki dan perempuan yang bukan mahramnya, para wisatawan senantiasa menjaga aurat di kawasan wisata, tetap dengan harga yang masuk akal dan ramah bagi para wisatawan serta meningkatkan daya tarik wisatawan terhadap objek-objek wisata religi seperti Masjid Raya Syahabuddin. Di sisi lain, para wisatawan juga dituntut menjaga kebersihan dan keasrian kawasan wisata sesuai dengan nilai-nilai kebersihan dalam ajaran Islam, 
misalnya membuang sampah pada tempatnya dan lain-lain.

Pengembangan pariwisata pada prinsipnya merupakan fokus utama pembangunan pemerintah dewasa ini, tidak hanya skala nasional namun meliputi dunia internasional yang akan berefek domino bagi segala sektor kehidupan masyarakat, baik ekonomi, budaya, politik bahkan agama.

Kecamatan Siak merupakan ibu kota Kabupaten Siak, disini pula terdapat ikon utama wisata Kabupaten Siak berupa Istana Asserayah el Hasyimiah atau lebih dikenal sebagai Istana Siak sebagai modal kuat Kabupaten Siak hingga memperoleh berbagai pengakuan dan penghargaan dari pemerinatah pusat di atas.

\section{METODE}

Tahapan penelitian yang telah dilakukan adalah wawancara. Wawancara dilakukan kepada Dinas Kebudayaan Dan Pariwisata Kabupaten Siak, Biro Perjalanan, Hotel, Dan Wisatawan yang ada di Kecamatan Siak. Wawancara ini bertujuan untuk megeksplorasi informasi mengenai realita pariwisata halal.

Selain itu, yaitu survey kepada wisatawan yang berada dalam dua lokasi wisata yang berada di daerah kecamatan Siak. Survey ini bertujuan untuk mengetahui potensi pariwisata halal dan gambaran umum pariwisata halal. Teknik Pengumpulan Data Teknik pengumpulan data yang dilakukan penulis menggunakan dua cara, wawancara, observasi dan dokumentasi (Arikunto, 2010).

Wawancara dilakukan dengan pengelola biro perjalanan dan hotel halal sebagai pelaku wisata, Dinas Kebudayaan Dan Pariwisata mewakili pemerintah, dan salah satu wisatawan, Majelis Ulama Indonesia (MUI) Kabuapten Siak. Penyebaran kuisioner dilakukan kepada wisatawan yang di temui di lokasi wisata. Observasi untuk mengamati fenomena secara langsung dalam rangka mengungkapkan sejarah jelas kondisi eksisting fenomena dilapangan, dan hasil dari pengamatan tersebut kemudian dikompilasi dengan mengarsipkannya melalui kegiatan dokumentasi.

\section{HASIL DAN DISKUSI}

Berdasarkan analisis penelitian, setidaknya dapat diungkapkan mengenai pengembangan pariwisata halal di Kabupaten Siak yakni meliputi objek dan daya tarik, aksesbilitas, amenitas, fasilitas pendukung dan kelembagaan.

\section{Objek dan daya tarik}

Objek dan daya tarik wisata pada penelitian ini bermakna fokus utama pengembangan dan strategi untuk menarik wisatawan terhadap destinasi wisata di Kecamatan Siak dalam menunjang Program Pariwisata Halal tahun 2019 sehingga mampu mengundang minat wisatawan untuk datang. Objek dan daya tarik wisata dimaksud terdiri dari beberapa kriteria, antara lain: promosi wisata dan objek wisata bersih.

Merujuk penuturan Kepala Dinas Pariwisata Kabupaten Siak Pemerintah Daerah khususnya Dinas Pariwisata Kabupaten Siak memang sedang gencargencarnya melakukan promosi wisata melalui berbagai media, seperti: pelaksanaan berbagai event pariwisata di Siak, media sosial, pamflet, iklan, dan sebagainya. Event-event pariwisata dimaksud ketika ditelusuri lebih lanjut adalah berbagai event baik seni, budaya maupun olahraga yang rutin diadakan oleh Pemerintah Daerah Kabupaten Siak setiap tahun (Putri, Tisnawati, dan Ardyanto, 2020). Berdasarkan hasil wawancara dengan kepalada Dinas Pariwisata Kabupaten Siak setidaknya ada beberapa obyek wisata yang dijadikan sebagai daya tarik dan promosi untuk menarik para wisatawan Seperti Tour De Siak, Siak International Serindit Boat Race, 
Ghatib Beghanyut, Festival Siak Bermadah (Listiawan dan Yohana, 2016).

Mengulas sedikit tentang pariwisata halal merupakan pariwisata yang mengendepankan nilai-nilai Islami dalam setiap aktvitasnya. Namun, istilah pariwisata halal secara definisi di kalangan pelaku wisata masih cenderung asing. Pariwisata halal lebih dimaknai sebagai wisata religi, yaitu kunjungan-kunjungan ke tempat ibadah untuk berziarah.

Padahal, pariwisata halal tidak terfokus pada objek saja, tetapi adab perjalanan dan fasilitas lainnya. Objek pariwisata halal pun tidak harus objek yang bernuansa Islam, seperti masjid dan peninggalan sejarah Islam. Objek pariwisata halal berlaku untuk semua tempat, kecuali tempat ibadah agama lain, dengan menghadirkan objek wisata yang bersih dan tertata rapi sesuai dengan nilainilai keislaman.

Data mencatat, dalam 1 (satu) hari di Istana Siak terdapat $5,30 \mathrm{~m}^{3}$ produksi sampah dari para wisatawan dan dari jumlah tersebut hanya $4,50 \mathrm{~m}^{3}$ volume sampah yang mampu diangkut dan dibawa ke tempat pembuangan sampah (TPA), dalam hal ini adalah TPA Bungaraya. Artinya, masih tersisa $0,80 \mathrm{~m}^{3}$ sampah per hari yang perlu menjadi perhatian stakeholder terkait jika ingin mewujudkan objek wisata yang bersih dan kaitannya dengan wisata halal.

\section{Aksesbilitas}

Aksesibilitas pada penelitian ini adalah kemudahan wisatawan dalam memperoleh akses informasi terkait objek serta pariwisata halal di Kecamatan Siak. Aksesibilitas dimaksud terdiri dari beberapa kriteria, antara lain: pusat informasi wisata serta fasilitas tempat ibadah dan toilet umum Pusat informasi wisata mengambil segmentasi tersendiri dalam mendukung kemajuan destinasi wisata halal khususnya di wilayah Kecamatan Siak.
Pusat informasi wisata memiliki peran penting dalam banyak hal, mulai dari promosi wisata secara berkelanjutan, media penghubung antara wisatawan dan pemerintah serta ruang terbuka yang memungkinkan wisatawan memperoleh informasi apa pun, kapan pun dan dimana pun (Putri, Tisnawati, dan Ardyanto, 2020). Dengan demikian, pusat informasi wisata memiliki klasifikasi, minimal berada dekat dengan wilayah objek wisata atau jika secara telekomunikasi mudah diakses dan aman.

Dari perspektif kehumasan ada tiga hal penting menyangkut Pusat Informasi: Pertama, informasi itu harus diperlakukan sebagaimana tujuan pendiriannya, yaitu sebagai tempat dimana informasi berpindah dari organisasi langsung kepada khalayak organisasi yang bersangkutan. Kedua, pusat informasi harus terdiri dari dua kelompok yakni, kelompok pertama yang bertugas melayani masyarakat secara langsung, menerima pertanyaan dan menyediakan jawaban. Kelompok kedua, disebut dengan coordinating agency (agen koordinasi) yaitu yang berfungsi sebagai titik hubung, antara pusat informasi dengan unit, serta staf organisasi. Agen koordinasi bertugas mencari informasi, dengan menghubungi atau menemui para staf yang ada pada unit-unit. Informasi atau jawaban yang diperoleh dikirim ke kelompok pertama yang ada di pusat informasi.Sebagai satusatunya sumber keterangan bagi Pusat Informasi, coordinating agency itu juga melakukan kontrol yaitu: informasi apa saja yang pernah dikeluarkan Pusat Informasi kepada masyarakat. Ketiga, Pusat Informasi tidak boleh bersifat dadakan yang dibentuk karena diterpa krisis. Pusat Informasi harus memiliki kredibilitas yang sudah terbentuk lama sebelum krisis apapun yang muncul. Pusat Informasi harus telah diakui menjadi sumber informasi yang tepat pada masa normal (atau ketika belum ada krisis). Bagian ini harus telah memiliki mekanisme kerja yang baik dimana aliran 
informasi antara unit-unit organisasi kepada Pusat Informasi tidak lagi menemui kendala. Pusat Informasi sudah harus diterima keberadaannya di lingkungan baik dalam kondisi normal maupun krisis.

Berdasarkan wawancara penelitian bahwa diketahui Pusat Informasi Wisata, khususnya wisata halal di Kabupaten Siak secara daring dan terstruktur dikelola oleh Dinas Pariwisata Kabupaten Siak, melalui link website https://pesonasiak.id/ sebagaimana dibahas pada bagian sebelumnya. Di sisi lain, Pemerintah Daerah Kabupaten Siak juga tergabung dan menjalin kerja sama dengan Perkumpulan Pariwisata Halal Indonesia (PPHI) serta Siak Heritage Community (SHC).

Akomodasi wisata merupakan hal penting dalam memenuhi kebutuhan wisatawan yang sedang berwisata. Para wisatawan cenderung membutuhkan akomodasi yang memiliki beragam varian harga maupun macamnya. Bentuk akomodasi primer yang dibutuhkan wisatawan yaitu adanya tempat untuk menginap saat mereka melakukan perjalanan wisata.

\section{Amenitas}

Amenitas adalah berbagai fasilitas di luar akomodasi yang dapat dimanfaatkan wisatawan selama berwisata di suatu destinasi atau semua bentuk fasilitas yang memberikan pelayanan bagi wisatawan untuk segala kebutuhan selama tinggal atau berkunjung pada suatu daerah tujuan wisata, dalam hal ini adalah Kecamatan Siak. Amenitas dimaksud terdiri dari beberapa kriteria, yakni: fasilitas tempat ibadah dan toilet umum serta konsumsi halal dan murah Untuk meningkatkan jumlah wisatawan, selain dikelola dengan benar, pengelola tempat wisata juga harus memperhatikan sarana kepariwisataan yang diberikan. Sarana kepariwisataan (tourism infrastructure) adalah semua fasilitas yang memungkinkan agar prasarana kepariwisataan dapat hidup dan berkembang serta dapat memberikan pelayanan kepada wisatawan untuk memenuhi kebutuhan mereka yang beranekaragam.

Dalam konsep wisata halal tidak ada perubahan apapun tentang destinasi wisata. Pembedanya disini adalah kenyamanan dalam beribadah, kemudahan mendapatkan produk makanan halal, serta lingkungan yang syar'i dan bebas maksiat baik dari pelayanan, fasilitas penunjang, lingkungan hotel, SPA hingga restoran. Jadi prinsip industri pariwisata halal adalah untuk semua orang dalam segala bentuk produk pariwisata dengan tetap memperhatikan nilai-nilai yang tidak bertentangan dengan syariat Islam.

Sarana dan prasarana merupakan salah satu indikator penting dalam pengembangan pariwisata. Kelengkapan sarana dan prasarana tersebut akan ikut menentukan keberhasilan suatu daerah menjadi daerah tujuan wisata. Pada awalnya, pariwisata halal sangat dikaitkan dengan segmen pasar muslim yang berkebutuhan khusus, yaitu agar tidak meninggalkan kewajiban ibadah dikala sedang melakukan kegiatan wisata. Namun pada akhirnya terminologi pariwisata halal juga diterima oleh pasar non muslim yang memahami pariwisata halal sebagai kegiatan wisata yang lebih memberikan jaminan terhadap keamanan dan kenyamanan seperti tempat wisata, akomodasi dan makan minumnya.

Berdasarkan wawancara kepada instansi pemerintah terkait, dapat diketahui bahwa fasilitas pendukung diluar akomodasi yang disediakan diantaranya, Fasilitas Tempat Ibadah dan Toilet Umum dam Konsumsi Halal dan Murah.

\section{Fasilitas Pendukung}

Sebagai sebuah organisasi, pariwisata merupakan suatu sistem, yang mempunyai unsur-unsur yang satu sama lain saling terkait dan berhubungan satu sama lain. Keberadaan 
(eksistensi) dan keeratan hubungan unsurunsur itu menggambarkan sampai seberapa kuat Sistem Kepariwisataan tersebut. Apabila salah satu unsur tidak ada atau lemah, maka sudah dipastikan kesisteman pariwisata akan terganggu atau tersendat-sendat kegiatannya. Karenanya dalam mengelola kepariwisataan diperlukan Manajemen Pariwisata yang betul-betul handal dan tepat sasaran.

Implikasinya, pariwisata merupakan fenomena yang multidimensional dan multisektoral yang harus dilihat dalam satu kesatuan sistem, yang berada di dalam sistem yang lebih luas. Pada titik ini lah, fasilitas pendukung pariwisata kemudian dianggap sebagai instrument penting dalam mendongkrak popularitas wisata suatu kawasan. Fasilitas pendukung pariwisata dimaksud terdiri dari beberapa kriteria, antara lain: kendaraan dan jalur transportasi serta penanganan situasi tanggap darurat.

Fasilitas pendukung tersebut diantaranya Kendaraan dan Jalur Transportasi seperti Bus, becak motor dan becak kayuh dan odong-odong kemudian antisipasi Penanganan Situasi Tanggap Darurat, seperti patroli bersama dan giat rutin Satpol PP, kepolisian dan Damkar.

\section{Kelembagaan}

Jika merujuk kepada Peraturan Pemerintah Nomor 50 Tahun 2011 tentang Rencana Induk Pembangunan Kepariwisataan Nasional Tahun 2010-2025, Kelembagaan Kepariwisataan adalah kesatuan unsur beserta jaringannya yang dikembangkan secara terorganisasi, meliputi pemerintah, pemerintah daerah, swasta dan masyarakat, sumber daya manusia, regulasi dan mekanisme operasional, yang secara berkesinambungan guna menghasilkan perubahan ke arah pencapaian tujuan di bidang kepariwisataan.

Oleh karena itu, berdasarkan Peraturan Pemerintah Nomor 50 Tahun 2011 tentang (RIPPARNAS), (Rifan dan Fikriya, 2020) secara umum pengembangan

konsep kelembagaan lebih berorientasi kepada bagaimana pemerintah kabupaten dapat meningkatkan partisipasi semua pihak dalam rangka pengembangan kepariwisataan. Dalam konteks pelaksanaan program dan kegiatan nantinya memang merupakan tugas dan tanggungjawab dari pemerintah, tetapi peran serta masyarakat, lembaga masyarakat dan pihak swasta diharapkan dapat lebih berperan. Dengan demikian, kelembagaan yang dimaksud pada penelitian ini, terdiri dari beberapa kriteria, antara lain: penguatan organisasi kepariwisataan dan pembangunan SDM pariwisata.

Pembentukan kelembagaan dalam pengembangan pariwisata, diperlukan kesesuaian pada tahap mana atau fase dalam siklus sebuah destinasi pariwisata (life cycle destination). Tahap eksplorasi akan berbeda jumlah dan kualitas lembaganya, begitu pula manakala sudah pada tahapan yang lebih tinggi misalnyapengembangan (involvement), akan berbeda pula tipologi keberadaan lembaga pariwisatanya.

Kemajuan pariwisata banyak dipengaruhi oleh profesionalisme dan eksistensi lembaganya (tourism institutions). Semakin maju lembaga pariwisata (kuantitas dan kualitas) maka cenderung akan semakin maju pula kemajuan pariwisata dalam suatu daerah. Oleh karena itu dalam usaha mencapai hal tersebut, Pariwisata di Kecamatan Siak dalam usaha pengembangannya saat ini, diperlukan langkah-langkah praktis dalam membangun beberapa lembaga pariwisata.

Undang-Undang Nomor 10 Tahun 2009 tentang kepariwisataan menyatakan bahwa pembangunan kepariwisataan diperlukan untuk mendorong pemerataan kesempatan berusaha dan memperoleh manfaat serta mampu menghadapi tantangan perubahan kehidupan lokal, nasional, dan global. Menindaklanjuti peraturan perundangundangan tersebut, Kabupaten Siak 
kemudian mengeluarkan kebijakan berupa Peraturan Daerah Nomor 12 Tahun 2012 tentang Rencana Induk Pengembangan Pariwisata di Kabupaten Siak.

\section{KESIMPULAN}

Berdasarkan hasil analisis yang telah dilakukan terkait pengembangan destinasi wisata, objek dan daya tarik wisata, bahwa telah dilakukan upaya dengan mengoptimalisasikan melalui promosi berkesinambungan serta inisiatif untuk menjaga kebersihan dan kerapian kawasan wisata. Begitu pula dengan aksesibilitas, telah terjalin kerjasama antara pemerintah daerah bersama Perkumpulan Pariwisata Halal Indonesia (PPHI) serta Siak Heritage Community (SHC) yang ditunjang pembangunan hotel oleh beberapa pengembang. Dari sisi amenitas, dikarenakan Siak kental dengan nuansa Melayu dan Islam maka tidak sulit menemukan tempat ibadah, didukung dengan kehadiran toilet-toilet umum yang punya bentuk khas dengan kesan menarik. Begitu pula dengan kehadiran keanekaragam konsumsi halal dan murah bagi wisatawan. Fasilitas pendukung dalam bentuk kendaraan dan jalur transportasi serta penanganan situasi tanggap darurat juga sudah cukup baik diimbangi dengan hubungan kelembagaan yang semakin terjalin erat antar stakeholder pariwisata.

\section{REFERENSI}

Chookaew, Sureerat et al. (2015). Increasing Halal Tourism Potential at Andaman Gulf in Thailand for Muslim Country. Journal of Economics, Business and Management 3(7), 739-41.

Destiana, Riska, dan Retno Sunu Astuti. (2019). Pengembangan Pariwisata Halal di Indonesia. In Conference on Public Administration and Society, .

Listiawan, Reza, dan Nova Yohana. (2016). Strategi Promosi Dinas Pariwisata Kabupaten Siak Dalam Mempromosikan
Kesenian Budaya Melayu Melalui Kegiatan Siak Bermadah. Jurnal Online Mahasiswa Fakultas Ilmu Sosial dan Ilmu Politik Universitas Riau, 3(2).

Moira, Polyxeni, Dimitrios Mylonopoulos, dan Aik Kondoudaki. (2012). The Management of Tourist's Alimentary Needs by the Tourism Industry. the Parameter of Religion. International Journal of Culture and Tourism Research 5(1), 129-40.

Putri, Novia, M.P, Endah Tisnawati, dan Setiawan Ardyanto. (2020). Penerapan Nilai-Nilai Regionalisme Arsitektur Pada Bangunan Pusat Informasi Wisata Kabupaten Cilacap. Jurnal Arsitektur GRID 2(1), 20-25.

Rifan, M, dan Hilmi Inaya Fikriya. (2020). Disharmonisasi Periode Pemberlakuan Rencana Induk Pembangunan Kepariwisataan Daerah di Indonesia (Implementasi Peraturan Pemerintah Nomor 50 Tahun 2011 tentang Rencana Induk Pembangunan Kepariwisataan). Jurnal Kepariwisataan Indonesia: Jurnal Penelitian dan Pengembangan Kepariwisataan Indonesia 14(2), 141-58.

Sidiq, Siti Sofro, dan Abdul Sidiq. (2015). Atraksi Wisata Religi di Masjid Syahbuddin Kabupaten Siak Provinsi Riau. Jurnal Online Mahasiswa Fakultas Ilmu Sosial dan Ilmu Politik Universitas Riau, 2(2).

Sofyan, Riyanto. (2012). Prospek Bisnis Pariwisata Syariah. Buku Republika.

Sumarno, Alim. (2012). Perbedaan Penelitian Dan Pengembangan. Elearning: Unesa.

Syamsuadi, Amir. (2018). Membangun Demokrasi Pemerintahan di Riau Dalam Perspektif Budaya Melayu. Jurnal Dinamika Pemerintahan 1(1), 1-10.

Widagdyo, Kurniawan, Gilang. (2015). Analisis Pasar Pariwisata Halal Indonesia. Tauhidinomics: Journal of Islamic Banking and Economics 1(1), 73-80. 